\title{
AKTIVITAS HATI TIKUS (RATTUS SP) YANG DIBERI RANSUM MENGANDUNG TEPUNG DAUN KALIANDRA (Calliandra calothyrsus) DAN KULIT NANAS (Ananas comosus) SELAMA MASA PERTUMBUHAN
}

\author{
LIVER ACTIVITY OF RAT (RATTUS SP) THAT GIVEN CALLIANDRA \\ (Calliandra calothyrsus) LEAF MEAL AND PINEAPPLE (Ananas comosus) \\ PEEL IN THE DIETS DURING THE GROWTH PERIOD
}

\author{
Iriani Setyawat ${ }^{1 *}$, I Gusti Ngurah Agung Dewantara Putra ${ }^{2}$, Ni Gusti Ketut Roni ${ }^{3}$ \\ Prodi Biologi dan 2 Prodi Farmasi, Fakultas MIPA, Universitas Udayana \\ 3 Prodi Peternakan, Fakultas Peternakan, Universitas Udayana \\ *Email: iriani_setyawati@unud.ac.id
}

Naskah diterima 26 Maret 2017, Naskah disetujui 16 Juni 2017

\section{INTISARI}

Daun Calliandra calothyrsus mengandung protein 17-28\% karena itu potensial sebagai sumber protein pakan ternak, namun tanaman ini mengandung condensed tannin cukup tinggi (>10\%) yang bersifat antinutrisi. Penambahan enzim protease (bromelin) pada pakan yang mengandung tanin ini diharapkan dapat mengatasi dampak negatif tanin. Bromelin dapat diperoleh dari tanaman nanas (Ananas comosus) termasuk dari kulit buahnya. Penelitian ini adalah pemberian pakan pada tikus jantan dan betina pasca sapih selama masa pertumbuhan dengan Rancangan Acak Lengkap pola faktorial berjenjang 4X4 dengan level substitusi tepung daun kaliandra 0 ; 10; 17,5 dan 25\% dalam ransum (main factor) dan level aditif kulit nanas 0; 4,35; 8,70 dan 13,05 g/ekor/hari (sub factor). Tikus dibagi menjadi 16 kelompok dan diberi perlakuan ransum selama dua bulan. Hasil penelitian terhadap aktivitas organ menunjukkan tidak ada interaksi antara kaliandra dan kulit nanas terhadap kadar SGOT (Serum Glutamate Oxalloacetate Transaminase) dan SGPT (Serum Glutamate Pyruvate Transaminase) darah. Kadar SGOT dan SGPT tidak dipengaruhi oleh semua level kulit nanas dalam ransum. Semua level kaliandra tidak mempengaruhi kadar SGOT, namun 17,5 dan 25\% kaliandra dalam ransum meningkatkan kadar SGPT.

Kata kunci: kaliandra, kulit nanas, SGPT, SGOT

\begin{abstract}
Calliandra calothyrsus leaves contain $17-28 \%$ protein thus potential as a protein source in animal diet. However, it also contain a high antinutrition of condensed tannins (>10\%). The addition of protease enzymes (bromelain) in the diet containing tannins is expected to overcome the negative effects of tannins. Bromelain can be obtained from the pineapple plant (Ananas comosus) including the peel. This study was a feeding experiment on weaned male and female rats during the growth period. This study used a completely randomized design of 4x4 factorial design. The main factor was Calliandra leaf meal substitution levels of $0 ; 10 ; 17.5$ and $25 \%$ in the diet. The sub factor was pineapple peel additive levels of $0 ; 4.35 ; 8.70$ and $13.05 \mathrm{~g} / \mathrm{rat} /$ day. Weaned rats were divided into 16 groups and they were fed for two months during growth period. The study showed that there was no interaction between calliandra leaves and pineapple peels on the rat liver activity including the blood levels of SGOT and SGPT levels. SGPT and SGOT levels were not affected by all levels of pineapple peels in the diets. All calliandra levels did not affect the level of SGOT, but 17.5 and $25 \%$ calliandra in the diets increased SGPT level.
\end{abstract}

Keywords: calliandra, pineapple peel, SGPT, SGOT

\section{PENDAHULUAN}

Daun kaliandra memiliki kandungan protein cukup tinggi $20-25 \%$, namun kadar tanin terutama tanin terkondensasi juga lebih tinggi dibandingkan jenis legum yang lain. Tanin secara alami merupakan senyawa polifenol dalam tanaman yang mampu mengikat mole- kul protein, juga dapat membentuk kompleks dengan karbohidrat, polisakarida, selulosa, mineral, membran sel bakteri, serta enzim yang terlibat dalam pencernaan protein dan karbohidrat (Cannas, 2008).

Tanin dalam pakan dapat mengurangi digestibilitas protein pakan pada non ruminansia (Jansman, 1993). Penelitian pada hewan percobaan menunjukkan turun- 
nya pertumbuhan maupun pertambahan berat badan. Kombinasi tanin dan protein menyebabkan protein tahan terhadap enzim proteolitik (tanin bersifat inhibitor protease). Senyawa ini umumnya menghambat tripsin, yang merupakan aktivator semua enzim yang dikeluarkan oleh pankreas (zymogen). Pakan yang kaya tanin dapat menyebabkan penurunan digestibilitas protein dan bahan kering akibat efek penghambatan tanin terhadap aktivitas tripsin dan enzim-enzim digestif lainnya di dalam usus tikus dan ayam (Los dan Podsedek, 2004).

Pada unggas, 7\% tanin dapat mengakibatkan kematian, 0,5-2,0\% tanin dapat menurunkan kecepatan pertumbuhan dan produksi telur. Sorgum yang tinggi kadar taninnya dapat menyebabkan abnormalitas perkembangan tungkai ayam (fase starter). Pemberian tanin pada tikus laktasi menurunkan bobot badan karena tanin dapat mengurangi energi, efisiensi pencernaan, asupan bahan kering dan nitrogen tercerna (Meyer dan Richardson, 1993). Tanin juga dapat mengganggu penyerapan kalsium (Chang et al., 1994) sehingga berpotensi mempengaruhi metabolisme tulang.

Kandungan tanin dalam daun kaliandra segar dapat diturunkan kadarnya diantaranya dengan mengkombinasikan pakan yang mengandung tanin dengan protease eksogen misalnya enzim bromelin yang bisa diperoleh dari limbah agroindustri tanaman nanas (Ananas comosus). Berlawanan dengan aksi tanin sebagai inhibitor protease, bromelin merupakan golongan enzim protease sistein yang terkandung dalam seluruh bagian tanaman nanas termasuk bagian kulitnya. Bromelin mampu menghidrolisis ikatan peptida pada protein atau polipeptida menjadi molekul yang lebih kecil atau asam amino (proteolitik eksogen) sehingga sangat bermanfaat membantu pencernaan protein. Enzim bromelin yang diisolasi dari kulit buah nanas berkisar 0,05-0,075\% (Gunawan, 2000) atau 0,075\% (Suhermiyati dan Setyawati, 2008).

Penelitian ini adalah percobaan pakan (feeding trial) menggunakan tikus sebagai hewan coba, karena baik kaliandra maupun limbah nanas masing-masing memiliki efek negatif yang akan dapat merugikan jika langsung dicobakan pada ternak. Jadi sebelum diperoleh level kombinasi yang tepat maka digunakan tikus percobaan. Dalam penelitian ini dikaji 16 macam ransum yang merupakan kombinasi tepung daun kaliandra dan/atau limbah kulit nanas dengan pakan komersial (konsentrat) pada tikus wistar jantan fase pertumbuhan.

\section{MATERI DAN METODE}

Bahan yang digunakan adalah daun kaliandra (Calliandra calothyrsus) dipetik tangan di daerah Mekarsari, Baturiti, Tabanan, dikering-anginkan hingga berat konstan (6 hari pelayuan), diblender dan diayak. Limbah kulit nanas (Ananas comosus) dikoleksi dari pedagang buah di Pasar Badung, sampel segar dihaluskan dan disimpan dalam refrigerator agar kandungan enzim bromelin (protease) tidak hilang. Konsentrat berupa pakan komplit butiran standar babi CP 551 (PT Charoen Pokphand) yang biasa untuk pakan tikus, dihaluskan menjadi tepung.

Setelah tepung daun kaliandra dan tepung konsentrat siap, juga kulit nanas segar telah dihaluskan, dilakukan pencampuran pakan dengan mixer hingga homogen, lalu bahan dimasukkan ke dalam mesin pelleting. Pelet yang dihasilkan langsung dikeringkan dengan freeze dryer hingga kering (6-8 jam), lalu dibungkus kantong plastik yang telah diberi label nomor ransum. Stok ransum disimpan dalam refrigerator untuk menjaga kadar tanin terkondensasi dan enzim bromelin selama masa perlakuan.

Tikus jantan galur wistar pascasapih diperoleh dari Fakultas Kedokteran Hewan Universitas Udayana, Denpasar, Bali. Tikus jantan pascasapih diadaptasi satu minggu kemudian dibagi menjadi 16 kelompok, masing-masing tiga ekor tikus sebagai ulangan. Tikus dikandangkan secara individual. Kondisi kandang diatur agar suasana gelap dan terang berlangsung secara alami dengan suhu kandang berkisar $23-25^{\circ} \mathrm{C}$. Kandang dibersihkan tiap empat hari. Selama adaptasi diberikan pakan standar secara ad libitum.

Selama perlakuan diberikan formulasi pakan sesuai kombinasi pada rancangan percobaan (Tabel 1). Pakan diberikan sesuai kebutuhan konsumsi harian tikus setiap hari pukul 16.00-17.00 WITA. Sisa pakan ditimbang 24 jam setelah pemberian untuk mengetahui jumlah konsumsi perharinya. Berat badan tikus ditimbang setiap dua hari sekali.

Penelitian ini menggunakan Rancangan Acak Lengkap pola faktorial 4x4 (16 kombinasi) masing-masing dengan 3 ulangan. Faktor pertama adalah level tepung daun kaliandra yaitu TDKo (tanpa tepung daun kaliandra), TDK1 (10\%), TDK2 (17,5\%), dan tertinggi TDK3 (25\%). Faktor kedua adalah level jus kulit nanas yaitu JKNo (tanpa jus kulit nanas), JKN1 (4,35 g/ekor/hari), JKN2 (8,70 g/ekor/hari) dan JKN3 (13,05 g/ekor/hari). Perlakuan diberikan selama 60 hari.

Tabel 1. Rancangan percobaan

\begin{tabular}{|c|c|c|c|c|c|}
\hline & \multicolumn{5}{|c|}{ Tepung Daun Kaliandra (T) } \\
\hline & Level & TDKo & TDK1 & TDK2 & $\mathrm{TDK}_{3}$ \\
\hline \multirow{12}{*}{$\begin{array}{l}\text { Jus Kulit } \\
\text { Nanas }\end{array}$} & \multirow[t]{2}{*}{ JKNo } & To.Jo $_{\mathrm{A}}$ & T1.Jo $_{\mathrm{A}}$ & $\mathrm{T}^{2 . \mathrm{Jo}_{\mathrm{A}}}$ & $\mathrm{T}_{3 .} \mathrm{Jo}_{\mathrm{A}}$ \\
\hline & & To.Jo $_{B}$ & $\mathrm{~T} 1 . \mathrm{Jo}_{\mathrm{B}}$ & $\mathrm{T}^{2 .} \mathrm{Jo}_{\mathrm{B}}$ & $\mathrm{T}_{3} . \mathrm{Jo}_{\mathrm{B}}$ \\
\hline & \multirow{4}{*}{ JKN1 } & To.Jo $_{\mathrm{C}}$ & T1.Jo $_{\mathrm{C}}$ & T2.Jo $_{\mathrm{C}}$ & $\mathrm{T}_{3} . \mathrm{JO}_{\mathrm{C}}$ \\
\hline & & To.J $1_{\mathrm{A}}$ & $\mathrm{T} . \mathrm{J} 1_{\mathrm{A}}$ & T2.J1 $_{\mathrm{A}}$ & $\mathrm{T}_{3 .} .{ }_{1}{ }_{\mathrm{A}}$ \\
\hline & & To.J $1_{B}$ & T1.J1 & T2.J $1_{\mathrm{B}}$ & $\mathrm{T}_{3 .} . \mathrm{J} 1_{\mathrm{B}}$ \\
\hline & & To.J $1_{\mathrm{C}}$ & T1.J1 ${ }_{C}$ & T2.J1 ${ }_{\mathrm{C}}$ & $\mathrm{T}_{3 .} \mathrm{J} 1_{\mathrm{C}}$ \\
\hline & \multirow[t]{3}{*}{$\mathrm{JKN} 2$} & To.J $2_{A}$ & $\mathrm{~T} 1 . \mathrm{J} 2_{\mathrm{A}}$ & $\mathrm{T} 2 . \mathrm{J} 2_{\mathrm{A}}$ & $\mathrm{T}_{3 .} \mathrm{J}{ }_{\mathrm{A}}$ \\
\hline & & To.J $_{B}$ & T1.J2 ${ }_{B}$ & T2.J ${ }_{B}$ & $\mathrm{~T}_{3 .} \mathrm{J}_{\mathrm{B}}$ \\
\hline & & To.J2 $\mathrm{C}$ & T1.J2 & ${ }^{\mathrm{T}} 2 . \mathrm{J}{ }_{\mathrm{C}}$ & ${ }^{\mathrm{T}} 3 . \mathrm{J} 2_{\mathrm{C}}$ \\
\hline & \multirow[t]{3}{*}{$\mathrm{JKN}_{3}$} & To.J $3_{\mathrm{A}}$ & T1.J $3_{\mathrm{A}}$ & ${ }^{\mathrm{T}} 2 . \mathrm{J}_{3_{\mathrm{A}}}$ & $\mathrm{T}_{3} . \mathrm{J}_{3} \mathrm{~A}$ \\
\hline & & To.J $3_{\mathrm{B}}$ & T1.J $3_{B}$ & $\mathrm{~T}_{2 .} \mathrm{J}_{3_{\mathrm{B}}}$ & $\mathrm{T}_{3} \cdot \mathrm{J}_{3 \mathrm{~B}}$ \\
\hline & & To.J ${ }_{3} \mathrm{C}$ & ${ }^{\text {T1.J }}{ }_{C}$ & ${ }^{\mathrm{T}} 2 . \mathrm{J}_{3} \mathrm{C}$ & ${ }^{\mathrm{T}} 3 . \mathrm{J}_{3} \mathrm{C}$ \\
\hline
\end{tabular}

Keterangan: TDK adalah tepung daun kaliandra yang mengandung tanin terkondensasi dengan empat level yaitu TDKo (tanpa tepung daun kaliandra), TDK1 (10\% tepung daun kaliandra), TDK2 (17,5\% tepung daun kaliandra), dan TDK3 (25\% tepung daun kaliandra). JKN adalah dosis jus kulit nanas yaitu JKNo (tanpa jus kulit nanas), JKN1 (4,35 g/ekor/hari jus kulit nanas), JKN2 (8,70 g/ekor/hari jus kulit nanas) dan $\mathrm{JKN}_{3}$ (13,05 g/ekor/hari jus kulit nanas). Subscript $\mathrm{A}, \mathrm{B}$ dan $\mathrm{C}$ menunjukkan ulangan tikus. 

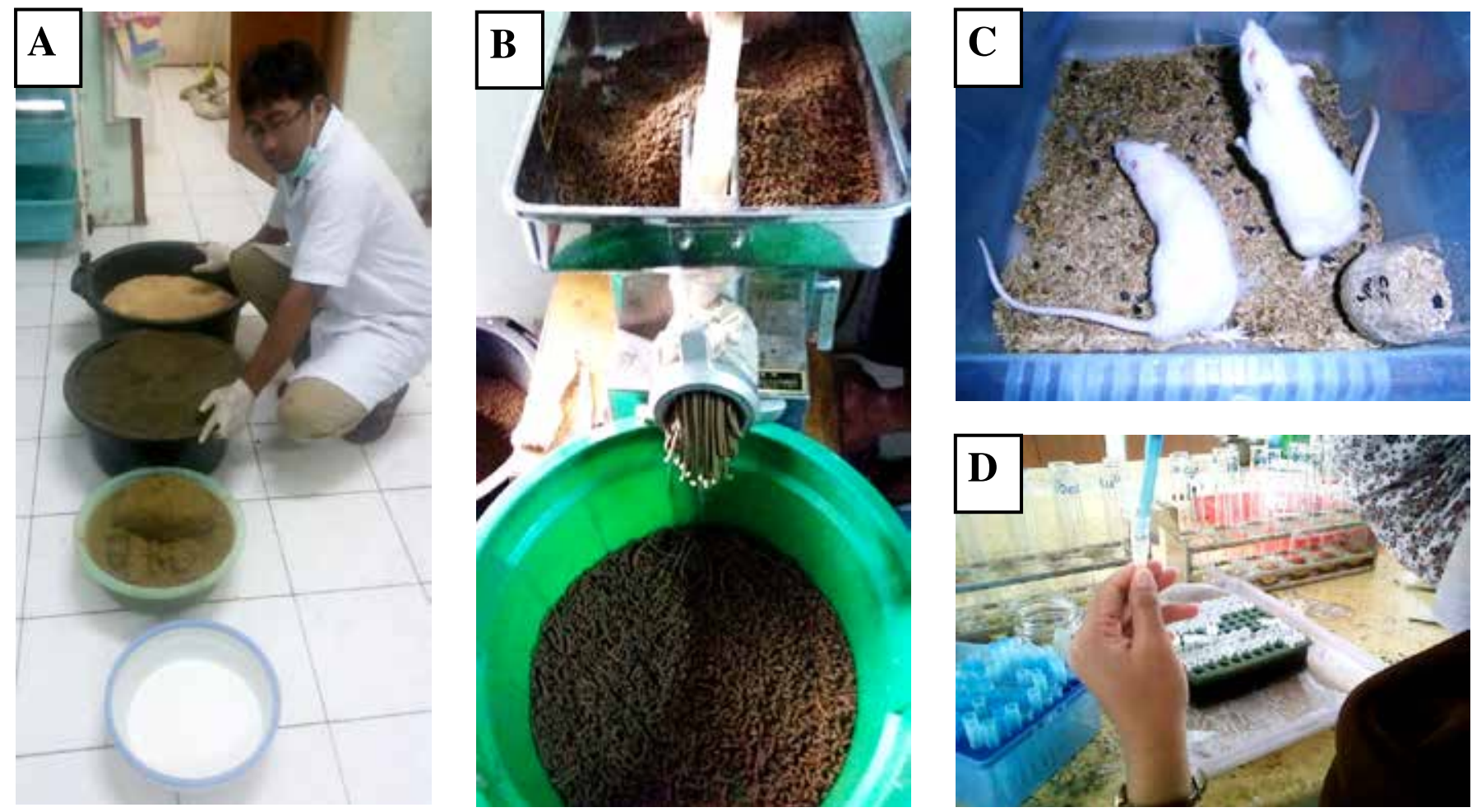

Gambar 1. Pelaksanaan penelitian

Keterangan: A. Bahan-bahan penyusun ransum (dari atas ke bawah: tepung pakan komersial/konsentrat, tepung daun kaliandra, jus kulit nanas segar, dan CMC), B. Proses pelleting pakan, C. Hewan coba (Rattus sp), D. Uji SGPT dan SGOT dari darah tikus.

Tikus dikorbankan di akhir perlakuan dengan injeksi ketamine intramuskular pada paha belakang. Darah diambil melalui plexus retroorbitalis menggunakan microcapilair untuk analisis darah. Darah dimasukkan ke dalam tabung eppendorf dan disentrifugasi 3000 rpm selama 10 menit. Serum diambil sebanyak $50 \mathrm{ml}$, dilanjutkan deproteinase dengan penambahan $500 \mu \mathrm{l}$ uranil asetat, disentrifugasi $3000 \mathrm{rpm}$ selama 5 menit dan supernatan diambil $500 \mu$ l. Penentuan kadar Serum Glutamate Oxalloacetate Transaminase (SGOT) dan $\mathrm{Se}$ rum Glutamate Pyruvate Transaminase (SGPT) plasma dilakukan sesuai dengan prosedur dengan memakai kit standar (Babu et al., 2012).

Analisis data dilakukan dengan program SPSS (Statistic Program for Social Sciences). Uji normalitas Kolmogorov-Smirnov untuk menguji normalitas data yang dihasilkan, uji homogenitas varians antar kelompok dengan Leven's Test, serta uji faktorial menggunakan General Linear Model (Univariate) dengan uji lanjut Duncan.

\section{HASIL}

Hasil analisis data menunjukkan tidak ada interaksi antara faktor utama (kaliandra) dengan faktor tambahan (kulit nanas) terhadap variabel kadar SGPT dan SGOT tikus jantan (Tabel 2).

Interaksi tepung daun kaliandra dengan jus kulit nanas tidak nyata. Huruf yang sama pada kolom yang sama menunjukkan tidak berbeda nyata $(\mathrm{P}>0,05)$. Keterangan:
Tabel 2. Kadar SGOT dan SGPT darah tikus jantan (IU/L).

\begin{tabular}{ccc}
\hline $\begin{array}{c}\text { Tepung Daun } \\
\text { Kaliandra (TDK) }\end{array}$ & SGOT (IU/L) & SGPT (IU/L) \\
\hline TDKo & $97,63 \mathrm{a}$ & $34,50 \mathrm{a}$ \\
TDK1 & $115,13 \mathrm{a}$ & $42,88 \mathrm{ab}$ \\
TDK2 & $117,38 \mathrm{a}$ & $50,00 \mathrm{~b}$ \\
TDK3 & $153,88 \mathrm{a}$ & $67,75 \mathrm{c}$ \\
Jus Kulit Nanas & & \\
(JKN) & & \\
JKNo & $105,38 \mathrm{a}$ & $45,13 \mathrm{a}$ \\
JKN1 & $112,13 \mathrm{a}$ & $46,00 \mathrm{a}$ \\
JKN2 & $114,63 \mathrm{a}$ & $47,63 \mathrm{a}$ \\
JKN3 & $151,88 \mathrm{a}$ & $56,38 \mathrm{a}$ \\
\hline
\end{tabular}

TDKo (tanpa tepung daun kaliandra), TDK1 (10\% tepung daun kaliandra), TDK2 (17,5\% tepung daun kaliandra), dan $\mathrm{TDK}_{3}$ (25\% tepung daun kaliandra), JKNo (tanpa jus kulit nanas), JKN1 (4,35 g/ekor/hari jus kulit nanas), JKN2 (8,70 g/ekor/hari jus kulit nanas) dan JKN3 (13,05 $\mathrm{g} /$ ekor/hari jus kulit nanas).

Level tepung daun kaliandra yang mengandung tanin maupun level jus kulit nanas yang mengandung bromelin dalam penelitian ini tidak mempengaruhi kadar SGOT. Sebaliknya, level jus kulit nanas tidak berpengaruh namun level tepung daun kaliandra meningkatkan kadar SGPT dalam darah tikus, signifikan $(\mathrm{P}<0,05)$ pada TDK3 (25\% tepung daun kaliandra). 


\section{PEMBAHASAN}

Kerusakan sel hati akan mempengaruhi kadar enzimenzim hati, bilirubin, dan protein dalam serum. Serum Glutamic Pyruvic Transaminase (SGPT) merupakan enzim yang berfungsi sebagai katalis berbagai fungsi tubuh. Enzim ini ditemukan paling dominan di sel hati, selain dalam konsentrasi kecil juga ditemukan di jantung, ginjal dan otot. Variasi kadar serum ini digunakan untuk mendiagnosis penyakit atau kerusakan organ hati. Serum Glutamic Oxaloacetic Transaminase (SGOT) adalah enzim yang ditemukan di jaringan atau sel yang mempunyai aktivitas metabolik tinggi misalnya di jantung, hati dan otot lurik. Enzim ini dikeluarkan ke aliran darah karena adanya jejas atau kematian sel.

Kerusakan yang relatif kecil pada sel hati akan meningkatkan kadar enzim SGPT dan SGOT di dalam darah. Namun, pada tingkat kerusakan yang luas dan parah, ketersediaan enzim SGPT dan SGOT di dalam sel hati sudah sangat rendah akibat kemampuan sel hati dalam mensintesis enzim tersebut sudah berkurang atau hilang sama sekali. Peningkatan kadar SGPT dalam darah terutama disebabkan oleh kerusakan sel hati dan sel otot rangka. Kerusakan hepatosit diawali perubahan permeabilitas membran yang diikuti dengan kematian sel. Peningkatan kadar SGOT dalam darah disebabkan oleh kerusakan hati yang parah dan disertai nekrosis, sehingga enzim dari mitokondria ikut keluar sel hati (Panjaitan, 2007).

Peningkatan kadar SGPT dapat digunakan sebagai alat diagnostik dalam menentukan kerusakan hepar secara umum. Kenaikan kadar enzim SGPT maupun SGOT di dalam darah disebabkan oleh sel-sel yang mengandung enzim ini mengalami nekrosis atau hancur. Enzim yang dikeluarkan sel kemudian masuk ke dalam peredaran darah (Noer, 2002). Dalam penelitian ini, peningkatan kadar SGPT dan SGOT dalam darah disebabkan pengaruh tanin dalam daun kaliandra. Masuknya tanin melalui jalur saluran pencernaan akan bermuara pada vena porta yang ada pada hepar. Dalam hepar, pemberian ransum mengandung tanin selama perlakuan akan menyebabkan akumulasi kandungan senyawa xenobiotik ini di dalam sel-sel hepatosit hati sehingga sel tidak mampu lagi mendetoksifikasinya. Akibatnya hepar akan mengalami kerusakan atau nekrosis dan mengeluarkan enzimnya ke peredaran darah.

Dalam penelitian ini, semakin tinggi pemberian tepung daun kaliandra yang mengandung tanin terkondensasi dalam ransum , cenderung meningkatkan kadar SGOT dan SGPT dalam darah tikus. Walaupun demikian, peningkatan tersebut tidak berbeda nyata dengan kontrol maupun dengan ransum yang tidak mengandung tepung daun kaliandra. Menurut Mitruka (1987), kadar normal SGOT tikus putih adalah $141 \pm 67,4$ IU/I. Pada penelitian ini, kadar SGOT tikus akibat pemberian tepung daun kaliandra masih normal berkisar 97,63-117,38 IU/L. Walaupun pada perlakuan level 25\% kaliandra, kadar
SGOT tikus mencapai 153,88 IU/L namun secara statistik tidak berbeda nyata. Kadar SGOT akibat peningkatan dosis jus kulit nanas juga masih dalam batas normal, walaupun pada level tertinggi kulit nanas, kadar SGOT tikus mencapai 151,88 IU/L.

Fenomena yang agak berbeda terjadi pada kadar SGPT tikus dimana peningkatan dosis kulit nanas dalam ransum tidak mempengaruhi kadar SGPT tikus. Sebaliknya, peningkatan level tepung daun kaliandra signifikan meningkatkan kadar SGPT tikus dibandingkan kontrol. Walaupun kandungan tanin dalam daun kaliandra dapat memicu kerusakan sel-sel hati, namun daun kaliandra juga mengandung senyawa fenolat yang berperan sebagai antioksidan yang melindungi sel-sel tubuh (dalam hal ini sel-sel hepatosit hati) dari serangan radikal bebas dan sebagai senyawa yang dapat mengkonjugasi senyawa xenobiotik agar lebih larut dalam air sehingga mudah diekskresikan melalui urin atau empedu.

Dari hasil analisis ransum pada penelitian sebelumnya, daun kaliandra terbukti dapat menjadi scavenger radikal bebas yang diduga berperan sebagai golongan antioksidan pemutus rantai, yang dapat memutuskan reaksi berantai peroksidasi lipid (Setyawati, unpublished). Radikal bebas dapat menyebabkan stres oksidatif. Hal ini ditandai dengan rusaknya membran sel dan rusaknya protein, termasuk enzim yang merupakan golongan protein fungsional akibat gangguan pada permeabilitas dan fungsi membran itu sendiri (Mohssen, 2001). Selain itu, tanin dalam daun kaliandra merupakan senyawa polifenol yang merupakan salah satu golongan antioksidan, suatu senyawa kimia yang dapat menghambat terjadinya proses oksidasi yang dipicu oleh radikal bebas.

Faktor lain yang mempengaruhi hasil penelitian ini adalah hewan uji tikus putih yang digunakan masih dalam fase pertumbuhan dan belum dewasa. Hewan muda kemungkinan masih memiliki kemampuan regenerasi sel yang tinggi terutama pada sel-sel hepatosit hati apabila ada kerusakan pada organ tubuhnya, dibandingkan dengan hewan dewasa atau tua. Dengan demikian, lebih cepat terjadi pemulihan sel-sel hati akibat paparan toksikan sehingga kadar SGOT dan SGPT masih dalam batas normal.

\section{SIMPULAN}

Berdasarkan hasil penelitian, ransum konsentrat yang disubstitusi dengan $25 \%$ tepung daun kaliandra tanpa maupun dengan aditif jus kulit nanas, signifikan meningkatkan kadar SGPT darah, yang mengindikasikan telah terjadi gangguan fungsi hati pada tikus.

\section{KEPUSTAKAAN}

Babu A.V.L., G. Arunachalam, K.Narasimha, Jayaveera, Varadharajan, M.S. Banu. 2012. Hepatoprotective Activity of Methalonic Extract of Ecrobolium viride (FOR SSK) Alston Roots Against Carbon Tetrachlo- 
ride Induce Hepatocity. IRJP. 3(8)

Cannas A. 2008. Tannins: Fascinating but Sometimes Dangerous Molecules, USA: Department of Animal Science, Cornell University.

Chang, M.C.J., J.W. Bailey, J.L. Collins. 1994. Dietary Tannins from Cowpeas and Tea Transiently Alter Apparent Calcium Absorption but not Absorption and Utilization of Protein in Rats, J. Nutr. 124: 283-288.

Gunawan. 2000. Keempukan, pH dan Daya Mengikat Air Otot Semitendinosus Sapi Peranakan Ongole pada Berbagai Taraf Suhu dan Konsentrasi Perendaman Sari Hati Nanas Muda [Skripsi], Bogor: IPB.

Jansman, A.J.M. 1993. Tannins in Feedstuffs for Simple Stomached Animals, Nutrition Research Reviews 6: 209-236.

Los, J., A. Podsedek. 2004. Tannins from Different Foodstuff as Trypsin Inhibitors, Pol. J. Food Nutr. Sci. 13/54(1): 51-55.

Meyer, M.W., C. Richardson. 1993. The Effects of Chronic Tannic Acid Intake on Praire Vole (Microtus ochrogaster) Reproduction, J.of Chemistry Ecology 19(7): 1577-1585.
Mitruka, M. 1987. Clinical Biochemical and Hematological Reference Values in Normal Experimental Animals and Normal Humans. Second Edition. Masson Publishing. USA.

Mohssen, M. 2001, Biochemical and Histopathological Changes in Serum Creatinine and Kidney Induced by Inhalation of Thimet (Phorate) in Male Swiss Albino Mouse, Mus musculus. Enviro. Res. (A) 87: 31-36.

Noer, H.M.S. 2002. Fisiologi dan Pemeriksaan Biokimia Hati, dalam Suparman. Ilmu Penyakit Dalam Hewan. Jilid 1 Edisi 9. Balai Penerbit FK UI. Jakarta.

Panjaitan, R.G.P., E. Handharyani, Chairul, Masriani, Z. Zakiah, W. Manalu. 2007. Pengaruh Pemberian Karbon Tetraklorida terhadap Fungsi Hati dan Ginjal Tikus, Makara, Kesehatan 11(1): 11-16.

Suhermiyati, S., S.J. Setyawati. 2008. Potensi Limbah Nanas untuk Peningkatan Kualitas Limbah Ikan Tongkol sebagai Bahan Pakan Unggas, Animal Prod. 10(3): 174-178. 